Journal of Animal and Veterinary Advances 10 (19): 2612-2617, 2011

ISSN: $1680-5593$

(C) Medwell Journals, 2011

\title{
A Retrospective Study of Reproductive Conditions and Requested Procedures in Dogs in South Western Nigeria: 1999-2008
}

\author{
O. Ajala Oluwatoyin and O.E. Fayemi \\ Department of Veterinary Surgery and Reproduction, University of Ibadan, Ibadan, Nigeria
}

\begin{abstract}
The reproductive conditions and requested procedures encountered in dogs in Southwestern Nigeria were surveyed using the clinical records of the state veterinary hospitals and some private veterinary clinics from January 1999 to December 2008 in order to document and compare their prevalence's. The most frequent reproductive conditions and requested procedures of dogs encountered were: requests for orchidectomy $33.0 \%$, Transmissible Venereal Tumor (TVT) $10.1 \%$, requests for pregnancy diagnosis $8.1 \%$ and oestrus detection $6.1 \%$, mastitis $5.3 \%$, abortion $4.5 \%$, urogenital tract infection $4.1 \%$, orchitis $3.4 \%$, metritis $3.3 \%$, dystocia $2.9 \%$ and infertility $1.6 \%$. The female dogs were presented with significantly more reproductive conditions and requested procedures $(54.1 \%)$ than the male dogs $(45.2 \%)$ and missing data $(0.7 \%)(\mathrm{p}<0.05)$. The breeds of dogs presented at the clinics and the distribution of the reproductive conditions and requested procedures were: Alsatian $27.4 \%$, Rottweiler $2.3 \%$, Nigerian local dog $28.0 \%$, Bull Mastiff $0.4 \%$, Pit bull $0.5 \%$, Terrier $0.2 \%$, Doberman $0.2 \%$, Crossbreds 6.7, Great Dane 0.3\%, Boxer 0.2\%, Boer Bouele 0.3\%, Labrador $0.1 \%$ and missing data $34.4 \%$. The prevalence of diseases of reproduction and requested procedures did not follow any specific pattern during the period studied but the highest prevalence was recorded in year 2008 due to problems with record keeping in some states. Sequel to the results above, veterinarians in this region of country are therefore, warned and prepare of possible increase in the prevalence of diseases of reproduction and requested procedures due to increase in the importation of exotic breeds of dogs.
\end{abstract}

$\underline{\text { Key words: Retrospective, study, reproduction, conditions, procedures, dogs, South West }}$

\section{INTRODUCTION}

Dogs are the most primitive companion of man and have been domesticated as early as $8,000 \mathrm{BC}$ (Zeuner, 1963; Epstein, 1971; Oyeyemi et al., 2000). They are used for several purposes including sports, hunting, guide, guard, companionship, recreational purposes, biomedical research and models to study human diseases (Pfaffenberger and Scott, 1975; Oben and Oben, 1977; Johnson, 1999). This is because they share many biomedical and physiological characteristics with human (Johnson, 1999).

There are three broad classes of dogs in Nigeria. The exotic breeds which are pure bred dogs that have certain inherited traits and skills. They are imported into the country and some are now well adapted to the climate or weather of Nigeria while some have not (Ajala, 2010). Examples are German shepherd (Alsatian), Rottweiler, Doberman, Boer Bouele, Ridge back, Bull mastiff, Pit bull, Neopolitant mastiff and the Terriers. The other two classes are the Nigerian local breeds and the cross breeds of varying degree of two different pure breeds. For example, crossing of pure Alsatian and the Nigerian local breed, Alsatian and Rottweiler (Ajala, 2010). The dogs when they are not spayed or neutered are fertile creatures which reach reproductive maturity or puberty before 2 years of age (Nelson and Couto, 2003). The age of reproductive maturity varies greatly and depends on environmental factors, breed size and nutrition (Sokolowiski et al., 1997). The small breeds reach puberty at an earlier age than the large breeds of dogs (Pavia, 2009). Once matured female dogs have two to three oestrous period in a year but some are monoestrus (Floss and Root-Kurtritz, 2009; Davol, 2000; Nelson and Couto, 2003). The interoestrous period varies from 4-12 months (Nelson and Couto, 2003). The bitches have the potential to produce multiple litters of puppies per year (Pavia, 2009) but sometimes problems can develop leading to infertility or sterility. In the female infertility can manifest as failure to cycles, aberration of the oestrous cycle, aberration of the oestrus period, failure to conceive, prenatal death which can be due to abortion, embroyonic death, embryonic resorption or foetal death, perinatal death which can be due to still birth or neonatal mortality

Corresponding Author: Oluwatoyin Ajala, Department of Veterinary Surgery and Reproduction, University of Ibadan, Ibadan, Nigeria 
(Noakes et al., 2001). Male infertility can manifest as disturbances of the production, transportation and or storage of spermatozoa, aberration of libido, partial or complete inability to mate and problems of the accessory glands (Nelson and Couto, 2003).

Infertility of the both male and female dogs can have complex aetiology involving several factors singly or in combination. They are categorized as structural including congenital, acquired, neoplastic diseases and trauma affecting the anatomy of the reproductive tract (Arthur et al., 1989). Functional including endocrinological abnormalities or malfunctions and inflammatory lesions (Noakes et al., 2001). Infectious for example Brucella canis infection which may be sexually transmitted leading to infertility in the male by causing low sperm count or poor mobility and abortion in the female dogs (Okoh et al., 1978; Berthelot and Garin-Bastuji, 1993). Parasitic diseases such as trypanosomosis (Noakes et al., 2001). Managemental problems of which poor timing of mating was identified by (Nelson and Couto, 2003) as the main managemental failure leading to the failure of conception in the female dog. This usually occurs because of lack of understanding of the reproductive cycle of the bitch. Other causes of infertility in the female are abortion of unknown causes, mastitis and eclampsia.

In practice, the common diseases of reproduction of dogs that have been encountered include: Transmissible Venereal Tumour (TVT) (Moulton, 1961; Hipping, 1966; Idowu, 1983; Smith and Washbournm, 1998), Orchitis (Schiemann and Staak, 1971; Brum, 2010), Scrotal dermatitis (Riser, 1975), Dystocia (Johnston, 1986; Day, 2007), Vaginitis (Hirsh and Wiger, 1977; Spielman, 2010), Pyometra (Hardy and Osborne, 1974; Olson et al., 1986), Metitis (Noakes et al., 2001) and Pseudopregnancy (Jochle et al., 1978; Gobello et al., 2001).

The procedures commonly requested for by pet owners are orchidectomy (Morrow, 1986; Oyeyemi et al., 2000), oestrus detection (Schutte, 1967; Davol, 2000), pregnancy detection (Concannon et al., 1983; Noakes et al., 2001), ovariohysterectomy (Morrow, 1986; Day, 2007).

Reproductive diseases and requested procedures are becoming a major concern to dog owners and veterinarians in Nigeria because of the increasing values of dogs especially the exotic breeds. This study was conducted to generate a data bank on the prevalence of reproductive conditions and requested procedures in dogs in the Southwestern area of Nigeria which can serve as reference for Veterinarians and pet owners.

\section{MATERIALS AND METHODS}

Clinical records were obtained from Veterinary Clinics and hospitals in Oyo, Ondo, Osun, Lagos and Ekiti states. The following information were obtained for the period between January 1999 to December 2008: Date of presentation, the breed, sex, age, parity, reproductive conditions and requested procedures. The different rate of conditions and requested procedures were calculated in percentages. The differences between paired means were determined using the least significant differences (Bamgboye, 2006).

\section{RESULTS}

The reproductive conditions and procedures encountered in dogs in South western Nigeria between 1999 and 2008 in the male were: Orchidectomy, TVT, urogenital tract infections, orchitis, infertility, paraphimosis, scrotal dermatitis, scrotal wound, posthitis, sertoli cell tumour, cryptorchidism, phimosis, post orchidectomy complications, penal bleeding, balamitis, abnormal preputial discharge, prostatis and hernia. In the female, the list of the reproductive conditions and requested procedures were: TVT, pseudopregnancy, pregnancy diagnosis, oestrus detection, mastitis, abortion, urogenital tract infections, mertitis, leptospirosis, infertility, OVH, dystocia, vaginal prolapse, post partum check up, agalactia, pyometra, mating, fading puppy, still birth, brucellosis, retained placenta, extra pendulous mammary teat, macerated foetus, premature birth, whelping, mammary gland tumour, vaginitis, vulvovaginitis, sub involution of placenta sites, canine eclampsia (paresis), vaginal hyperplasia and traumatic mating.

The most frequent reproductive conditions and requested procedures encountered were: request for orchidectomy $33.2 \%$, TVT $10.1 \%$, request for pregnancy diagnosis $8.1 \%$ and oestrus detection $6.1 \%$ and mastitis, $5.3 \%$, abortion $4.5 \%$, urogenital tract infection $4.1 \%$, orchitis $3.4 \%$, Metritis $3.3 \%$ while all other less frequent conditions accounted for $21.4 \%$ and missing data $0.7 \%$ (Table 1-3).

There were significantly more reproductive conditions of dog in the female (54.1\%) than in the male $(45.2 \%)$ and missing data $(0.7 \%)(\mathrm{p}<0.05)$ in South Western Nigeria (Table 1-3).

The following were breeds of dogs encountered in the South Western Nigeria between January 1999 and December, 2008. Alsatian, Rottweiler, Nigerian Local, bull mastiff, pit bull, terrier, doberman, great dane, boxer, boerbouele, labrador and crosses of different degrees of these 
Table 1: Occurrence of reproductive conditions and procedures in both male and female dogs in South Western Nigeria (frequency above 3.0\%) Frequency $\mathrm{n}(\%)$

\begin{tabular}{lccr} 
Reproductive & & & \\
conditions and procedure & Male & Female & \multicolumn{1}{c}{ Total } \\
\hline Orchidectomy & $346(33.0)$ & - & $346(33.0)$ \\
TVT & $11(1.1)$ & $95(9.0)$ & $106(10.1)$ \\
Pregnancy diagnosis & - & $85(8.1)$ & $85(8.1)$ \\
Oestrus detection & - & $64(6.1)$ & $64(6.1)$ \\
Mastitis & - & $56(5.3)$ & $56(5.3)$ \\
Abortion & - & $47(4.5)$ & $47(4.5)$ \\
Urogenital tract infections & $23(2.2)$ & $20(1.9)$ & $43(4.1)$ \\
Orchitis & $36(3.4)$ & - & $36(3.4)$ \\
Metritis & - & $35(3.3)$ & $35(3.3)$ \\
Sub-total & $416(39.7)$ & $402(38.2)$ & $818(77.9)$ \\
\hline
\end{tabular}

Table 2: Occurrence of reproductive conditions and procedures in both male and female dogs in South Western Nigeria (frequency of $0.5-2.9 \%$ )

\begin{tabular}{|c|c|c|c|}
\hline \multirow{2}{*}{$\begin{array}{l}\text { Reproductive } \\
\text { conditions and procedure }\end{array}$} & \multicolumn{3}{|c|}{ Frequency n (\%) } \\
\hline & Male & Female & Total \\
\hline \multirow[t]{2}{*}{ Leptospirosis } & - & $5(0.5)$ & $5(0.5)$ \\
\hline & $1(0.1)$ & $16(1.5)$ & $17(1.6)$ \\
\hline Paraphimosis & $10(1.0)$ & - & $10(1.0)$ \\
\hline OVH & - & $7(0.7)$ & $7(0.7)$ \\
\hline Dystocia & - & $30(2.9)$ & $30(2.9)$ \\
\hline Vaginal prolapse & - & $8(0.8)$ & $8(0.8)$ \\
\hline Pseudo-pregnancy & - & $20(1.9)$ & $20(1.9)$ \\
\hline Scrotal dermatitis & $17(1.6)$ & - & $17(1.6)$ \\
\hline Post partum check up & - & $8(0.8)$ & $8(0.8)$ \\
\hline Agalactia & - & $7(0.7)$ & $7(0.7)$ \\
\hline Pyometra & - & $12(1.1)$ & $12(1.1)$ \\
\hline Mating & - & $5(0.5)$ & $5(0.5)$ \\
\hline Fading puppy & - & $5(0.5)$ & $5(0.5)$ \\
\hline Scrotal wound & $5(0.5)$ & - & $5(0.5)$ \\
\hline Still birth & - & $6(0.6)$ & $6(0.6)$ \\
\hline Posthitis & $6(0.6)$ & - & $6(0.6)$ \\
\hline Brucellosis & - & $6(0.6)$ & $6(0.6)$ \\
\hline Retained placenta & - & $6(0.6)$ & $6(0.6)$ \\
\hline Sub-total & $39(3.8)$ & $141(13.7)$ & $180(17.5)$ \\
\hline
\end{tabular}

Table 3: Occurrence of reproductive conditions and procedures in both male and female dogs in South Westem Nigeria (frequency below $0.5 \%$ )

\begin{tabular}{|c|c|c|c|}
\hline \multirow{2}{*}{$\begin{array}{l}\text { Reproductive } \\
\text { conditions and procedure }\end{array}$} & \multicolumn{3}{|c|}{ Frequency (\%) } \\
\hline & Male & Female & Total \\
\hline Extra pendulous mammary teat & - & $1(0.1)$ & $1(0.1)$ \\
\hline Setoli cell tumour & $3(0.3)$ & 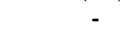 & $3(0.3)$ \\
\hline Cryptorchidsim & $4(0.4)$ & - & $4(0.4)$ \\
\hline Macerated foetus & - & $2(0.2)$ & $2(0.2)$ \\
\hline Premature birth & - & $2(0.2)$ & $2(0.2)$ \\
\hline Phimosis & $2(0.2)$ & - & $2(0.2)$ \\
\hline Whelping & - & $1(0.1)$ & $1(0.1)$ \\
\hline Post orchidectomy complications & $1(0.1)$ & - & $1(0.1)$ \\
\hline Mammary gland tumour & - & $4(0.4)$ & $4(0.4)$ \\
\hline Vaginitis & - & $3(0.3)$ & $3(0.3)$ \\
\hline Vulvovaginitis & - & $4(0.4)$ & $4(0.4)$ \\
\hline Sub involution of placenta site & - & $1(0.1)$ & $1(0.1)$ \\
\hline Canine eclampsia (Paresis) & - & $3(0.3)$ & $3(0.3)$ \\
\hline Penal bleeding & $2(0.2)$ & - & $2(0.2)$ \\
\hline Balanitis & $3(0.3)$ & - & $3(0.3)$ \\
\hline Vaginal hyperplasia & - & $2(0.2)$ & $2(0.2)$ \\
\hline Abnormal preputial discharge & $2(0.2)$ & - & $2(0.2)$ \\
\hline Traumatic mating & - & $2(0.2)$ & $2(0.2)$ \\
\hline Prostatis & $2(0.2)$ & - & $2(0.2)$ \\
\hline Hernia & $1(0.1)$ & - & $1(0.1)$ \\
\hline Sub-total & $19(1.7)$ & $23(2.2)$ & $42(3.9)$ \\
\hline Final total (Table 1-3) & $474(45.2)$ & $\begin{array}{l}566(54.1) \\
\text { Missing } \\
\text { data } 7(0.7)\end{array}$ & $1047(100.0)$ \\
\hline
\end{tabular}

Table 4: Percentage distribution of reproductive conditions and procedures in dogs in South Western Nigeria between 1999 and 2008

\begin{tabular}{lc}
\hline State & Percentage reproductive condition n (\%) \\
\hline Oyo & $382\left(36.5^{a}\right)$ \\
Ogun & $118\left(11.3^{b}\right)$ \\
Osun & $165\left(15.8^{b}\right)$ \\
Ondo & $136\left(13.0^{d}\right)$ \\
Ekiti & $136\left(13.0^{d}\right)$ \\
Lagos & $107\left(10.2^{c}\right)$ \\
Missing data & $3(0.3)$ \\
Total & $1047(100.0)$ \\
\hline Percentages with different superscripts are signific antly different from each \\
other $(\mathrm{p}<0.05)$
\end{tabular}

Table 5: Percentage distribution of reproductive conditions and proceeding of dogs in South Westem Nigeria (1999-2008)

\begin{tabular}{lr}
\hline Years & Frequency $(\%)$ \\
1999 & $117(11.2)$ \\
2000 & $132(12.6)$ \\
2001 & $108(10.3)$ \\
2002 & $103(9.9)$ \\
2003 & $85(8.1)$ \\
2004 & $62(5.9)$ \\
2005 & $73(7.0)$ \\
2006 & $67(6.4)$ \\
2007 & $79(7.5)$ \\
2008 & $218(21.0)$ \\
Missing data & $3(0.3)$ \\
Total & $1047(100.0)$ \\
\hline
\end{tabular}

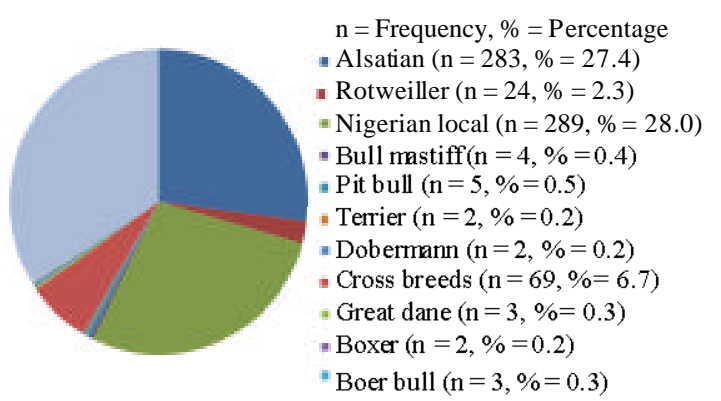

Fig. 1: Distribution of reproductive conditions of dogs between 1999 and 2008 among breeds (Labrador: $\mathrm{n}=1, \%=0.1$; Missing data: $\mathrm{n}=360, \%=34.4$; Total: $1047, \%=100$ )

pure breeds (Fig. 1). The Alsatian (27.4\%) and the Nigerian Local (28.0\%) dogs are the two major breeds of dogs with the highest reproductive cases (Fig. 1).

Oyo state had the highest occurrence of reproductive conditions of dogs $(36.5 \%)$ followed by Osun $(15.8 \%)$, Ondo and Ekiti states $(13.0 \%)$ then ogun $(11.3 \%)$ and lagos having the lowest $(10.2 \%)$ and missing data $3(0.3 \%)$ (Table 4).

The annual percentage distribution of reproductive conditions was highest in the year $2008(21.0 \%)$ and the lowest in the year $2004(5.9 \%)$ (Table 5) and the monthly distribution was highest in September (10.7\%) and lowest in July $(6.7 \%)$ (Table 6). 
Table 6: Monthly distribution of reproductive conditions and procedures in the South Westem Nigeria (1999-2008)

\begin{tabular}{lr}
\hline Years & Frequency $(\%)$ \\
\hline January & $102(9.80)$ \\
February & $71(6.80)$ \\
March & $82(7.90)$ \\
April & $90(8.60)$ \\
May & $72(6.90)$ \\
June & $72(6.90)$ \\
July & $70(6.70)$ \\
August & $99(9.50)$ \\
September & $112(10.70)$ \\
October & $92(8.80)$ \\
November & $95(9.15)$ \\
December & $87(8.30)$ \\
Missing data & $3(0.30)$ \\
Total & $1047(100.00)$ \\
Percentages with different superscripts are significantly different from each \\
other $(p<0.05)$
\end{tabular}

\section{DISCUSSION}

The list of common reproductive conditions and procedures in South Western Nigeria from January 1999 to December 2009 generated from this study is similar except with some new additional conditions, to those generated from Edo state of Nigeria from 1992-1995 by Oyeyemi et al. (2000). The new conditions show that some reproductive conditions which were not common before are now being introduced because of the increased importation of exotic breeds of dogs couple with uncontrolled breeding activities in the country. The distribution of reproductive conditions and procedures of dogs in the South Western Nigeria did not follow a particular trend during the period of this study. This might be due to the fact that the veterinary operations in some states in the region were disrupted because of some industrial disputes between the veterinarians and the Government and so many cases were not reported. It will be observed that in 2008 , the number of reproductive conditions and requested procedures recorded the highest frequency. This means that those state clinics and hospitals having problems had started operating better and with the importation of more breeds of dogs, reproductive problems might have increased. Reproductive conditions and procedures were reported throughout the months of the year but had the highest frequency during the month of September.

The female reproductive conditions and requested procedures in the dogs were higher than those of the male. This finding might have been as a sequel of the usual higher attention paid to female reproduction (Zemjanis, 1970) although, Oyeyemi et al. (2000) reported more reproductive cases in the males than in the female dogs. The higher prevalence of TVT in the female than in the male in this study is contrary to the observations of
Morrow (1986) that there seems to be no sex pre-dilection in the occurrence of TVT. However, this result may be due to the fact that castration accounts for $33.0 \%$ of the male cases and this could have reduced the incidence of TVT in the male because TVT is a disease of sexually active dogs and castration, certainly affects sexual activity.

Oyo state recorded the highest reproductive conditions and requested procedures followed by Osun, Ondo, Ekiti and Lagos states. The differences might be as a result of differences in the appreciation of veterinary care for pets and inadequate attention by people especially in mega cities like Lagos where because of their business schedules, many pet-owners do not have time to visit the veterinary clinics or hospitals, resulting in many cases not being captured.

\section{CONCLUSION}

In this survey, some breeds that have been known to be prone to dystocia for example, the Bull Mastiff, Pit Bull and Boston Terrier were among the breeds found in this region (Barber, 2003; Day, 2007). Therefore, pet owners and veterinarian in this region should be informed and so prepared for the possible increase in the prevalence of diseases and conditions of reproduction which used to have low prevalence such as dystocia.

\section{RECOMMENDATIONS}

There were some missing data in this study which might be due to inadequate record keeping of most clinics in the South Western region of Nigeria. It is therefore, recommended that the record section of all veterinary clinics and hospitals should be computerized and many more items included in the data base. Some additional data to be included are: breed, usage, nutrition, parity and age of dogs at presentation.

It is also recommended that the state governments in this region should give better attention to veterinary healthcare by providing better amenities to work with.

It was also discovered that there was no follow up of all reproductive cases treated in all the veterinary hospitals. Therefore, complications and the impact of interventions on future fertility of the dogs could not be studied. It is recommended that proper follow up should be given to all cases of reproduction treated in dogs and the clients should be made to comply.

It was observed that most dog owners and breeders seek veterinary help when they have emergencies. It is recommended that more enlightenment campaigns should be done in this region to educate clients on the importance of routine veterinary care and breeding education for their dogs. 


\section{REFERENCES}

Ajala, O.O., 2010. Some aspects of the reproductive biology and management practices in the Nigerian local bitches in Ibadan. Ph.D. Thesis, Faculty of Veterinary Medicine University of Ibadan, Ibadan, Nigeria.

Arthur, G.H., E.D. Noakes and H. Pearson, 1989. The Oestrus Cycle and its Control. In: Veterinary Reproduction and Obstetric (Theriogenology), Arthur, G.H., E.D. Noakes and H. Pearson (Eds.). 6th Edn., Builere Tindall, London, pp: 3-42.

Bamgboye, E.A., 2006. A Companion of Medical Statistics. 1st Edn., Ibipress and Publishing Co., Ibadan, pp: 216.

Barber, J.A., 2003. Parturitions and Dystocia. In: Small Animal Theriogenology, Kustritz, M.V.R. (Ed.). Butterworth Heinemann, Anim Print of Elsevier Science, USA, pp: 241-281.

Berthelot, Y. and B. Garin-Bastuji, 1993. Brucellosis in canines. Point Veterinarian, 25: 33-37.

Brum, D., 2010. Orchitis in dogs. Intelligent Content Corp. http://www.petplace.com/dogs/orchitis/pagel aspx.

Concannon, P., S. Whaley, D. Lein and R. Wissler, 1983. Canine gestation length: variation related to time of mating and fertile life of sperm. Am. J. Vet. Res., 44: 1819-1821.

Davol, P.A., 2000. Medical management of complications affecting delivery (whelping). http://bullydomain. com/article.php?article_id=84.

Day, J.W., 2007. Diseases of the female reproductive system. http://www.familyvet.com/Dogs/Female.html \#femaleinfert.

Epstein, H., 1971. The Origin of Domestic Animals of Africa. Vol. 2, Africana Publishing Corporation, New York.

Floss, J.L. and M. Root-Kurtritz, 2009. Reproductive management of the female dog. A Public Service Brochure from the American College of Theriogenologists. www.theriogenology.org.

Gobello, C., P.W. Concannon and J. Verstegen, 2001. A Review of Canine Pseudoprenancy. In: Recent Advances in Small Animal Reproduction, Ithaca, New York, USA.

Hardy, R.M. and C.A. Osborne, 1974. Canine pyometra: Pathophysiology, diagnosis and treatment of uterine and extrauterine lesions. J. Am. Anim. Hosp. Assoc., 10: 245-268.

Hipping, D.A., 1966. Observation on the tumour transmissible venereal tumor as seen in the bahamas. Vet. Rec., 79: 67-71.
Hirsh, D.C. and N. Wiger, 1977. The bacterial flora of the normal canine vagina compared with that of vaginal exudates. J. Small Anim. Pract., 18: 25-30.

Idowu, A.L., 1983. Cryosurgery of canine transmissible venereal tumour. Trop. Veterinarian, 3: 74-78.

Jochle, W., R. Ballobio and E. Disalle, 1978. Introduction of lactation in the beagle bitch with the prolaction inhibitor cabergoline dose, response and aspects of longterm safety. Theriogenology, 7: 113-120.

Johnson, P.D., 1999. Dogs in biomedical research lecture notes VSC443/534. Assistant Veterinary specialist, University Animal Care. University of Arizoba Tucson, A.Z.

Johnston, S.D., 1986. Parturition and Dystocia in the Bitch. In: Current Therapy in Theriogenology, Morrow, D.A. (Ed.). W.B. Saunder Company, Philadelphia, pp: 500-501.

Morrow, A.D., 1986. Transmissible Venereal Tumour (TVT) in Dogs. In: The Current Therapy in Theriogenology, Morrow, A.D. (Ed.). 2nd Edn., W.B. Saunders Co., Philadelphia, pp: 226-227.

Moulton, J.E., 1961. Tumours in Domestic Animals. University of California Press, Berkley, California.

Nelson, R.N. and C.G. Couto, 2003. Small Animal Internal Medicine. 3rd Edn., Mosby, New York, ISBN-13: 9780323017244 , pp: 1392.

Noakes, D., T.J. Parkinson and G.C.W. England, 2001. Arthur's Veterinary Reproduction and Obstetrics. 8th Edn., ElsevierLtd., ISBN-13: 978-0702025563, London, pp: 864.

Oben, S.J. and J.W. Oben, 1977. The Chinese wolf ancestor of new world dog. Sciences, 197: 533-535.

Okoh, A.E.S., I. Alexie and D.E. Agbonilahor, 1978. Brucellous in dogs in Kano State Nigeria. Trop. Anim. HH. Prod., 10: 219-224.

Olson, P.N., R.L. Jones and E.C. Mathner, 1986. The Use and Misuse of Vaginal Cultures in Diagnosing Reproductive Diseases in the Bitch. In: Current Therapy in Theriogenology, Morrow, D.A. (Eds.). W.B. Saunders Co., Philadelphia, ISBN: 0721665802 , pp: $469-475$.

Oyeyemi, M.O., V.O. Adetunji, G.A.T. Ogundipe and O.O. Babalobi, 2000. The prevalence of reproductive conditions in dogs in Edo state Nigeria. Proceedings of the 9th Symposium of International Society for Veterinary Epidemiology and Economics, Aug. 6-11, Breckenridge, Colorado, USA., pp: 1063-1065.

Pavia, A., 2009. Reproductive problems in dogs. http://petdoc.com/story/reproductive-prolems-dogs.

Pfaffenberger, C.J. and J.P. Scott, 1975. Early Rearing and Testing. In: Guide for the Blind, their Selection Development and Training. Pfaffenberger, C.J. (Ed.). Pergamon Press, New York. 
Riser, W.H., 1975. Carnivore Introduction. In: Anatomy of the Domestic Animals by Sission and Grossman, Riser, W.H. (Ed.). 5th Edn., W.B. Saunders Co., Philadelphian.

Schiemann, B. and C. Staak, 1971. Brucella melitensis in lmpala (Aephycenes malampus). Vet. Rec., 88: 344-354.

Schutte, A.P., 1967. Canine vaginal cytology III compilation and evaluation of cellular indices. J. Small Anim. Pract., 8: 313-317.

Smith, G.B. and J.B. Washbournm, 1998. Infective sarcomata in dogs. Br. Med. J., 2: 1807-1810.
Sokolowiski, J.H., D.G. Stover and F. Van Ranvenswa, 1997. Seasonal incidence of oestrus and interoestrous interval for bitches of seven breeds. J. Am. Vet. Med. Assoc., 171: 271-273.

Spielman, B., 2010. Vaginitis in dogs. Intelligent Content Corp. http://www.petplace.com/dogs/vaginitis-indogs/page1 .aspx.

Zemjanis, R., 1970. Diagnostic and Therapeutic Techniques in Animal Reproduction. 2nd Edn., Williams and Wilkins Co., Beltmore, pp: 29-43.

Zeuner, F.E., 1963. A History of Domesticated Animals. Harper and Roy, New York. 